Washington University School of Medicine

Digital Commons@Becker

Open Access Publications

2006

\title{
Lysosomal phospholipase A2 and phospholipidosis
}

\author{
Miki Hiraoka \\ University of Michigan - Ann Arbor \\ Akira Abe \\ University of Michigan - Ann Arbor \\ Ye Lu \\ University of Michigan - Ann Arbor \\ Kui Yang \\ Washington University School of Medicine in St. Louis \\ Xianlin Han \\ Washington University School of Medicine in St. Louis
}

See next page for additional authors

Follow this and additional works at: https://digitalcommons.wustl.edu/open_access_pubs

Please let us know how this document benefits you.

\section{Recommended Citation}

Hiraoka, Miki; Abe, Akira; Lu, Ye; Yang, Kui; Han, Xianlin; Gross, Richard; and Shayman, James A., "Lysosomal phospholipase A2 and phospholipidosis." Molecular and Cellular Biology. 26, 16. 6139-6148. (2006).

https://digitalcommons.wustl.edu/open_access_pubs/3069

This Open Access Publication is brought to you for free and open access by Digital Commons@Becker. It has been accepted for inclusion in Open Access Publications by an authorized administrator of Digital Commons@Becker. For more information, please contact vanam@wustl.edu. 


\section{Authors}

Miki Hiraoka, Akira Abe, Ye Lu, Kui Yang, Xianlin Han, Richard Gross, and James A. Shayman 


\section{Molecular and Cellular Biology}

\section{Lysosomal Phospholipase A2 and Phospholipidosis}

Miki Hiraoka, Akira Abe, Ye Lu, Kui Yang, Xianlin Han, Richard W. Gross and James A. Shayman

Mol. Cell. Biol. 2006, 26(16):6139. DOI:

10.1128/MCB.00627-06.

Updated information and services can be found at:

http://mcb.asm.org/content/26/16/6139

These include:

SUPPLEMENTAL MATERIAL

Supplemental material

REFERENCES

This article cites 18 articles, 10 of which can be accessed free at: http://mcb.asm.org/content/26/16/6139\#ref-list-1

CONTENT ALERTS

Receive: RSS Feeds, eTOCs, free email alerts (when new articles cite this article), more» 


\title{
Lysosomal Phospholipase A2 and Phospholipidosis $\dagger$
}

\author{
Miki Hiraoka, ${ }^{1}+$ Akira Abe, ${ }^{1}+$ Ye Lu, ${ }^{1}$ Kui Yang, ${ }^{2}$ Xianlin Han, ${ }^{2}$ \\ Richard W. Gross, ${ }^{2}$ and James A. Shayman ${ }^{1 *}$ \\ Nephrology Division, Department of Internal Medicine, University of Michigan, Ann Arbor, Michigan, ${ }^{1}$ \\ and Department of Medicine, Washington University, St. Louis, Missouri ${ }^{2}$
}

Received 11 April 2006/Returned for modification 17 May 2006/Accepted 27 May 2006

\begin{abstract}
A lysosomal phospholipase A2, LPLA2, was recently characterized and shown to have substrate specificity for phosphatidylcholine and phosphatidylethanolamine. LPLA2 is ubiquitously expressed but is most highly expressed in alveolar macrophages. Double conditional gene targeting was employed to elucidate the function of LPLA2. LPLA2-deficient mice ( $\mathrm{Lpla}^{-1-}$ ) were generated by the systemic deletion of exon 5 of the Lpla2 gene, which encodes the lipase motif essential for the phospholipase $\mathrm{A} 2$ activity. The survival of the $\mathrm{Lpla}^{-/-}$mice was normal. Lpla2 ${ }^{-/-}$mouse mating pairs yielded normal litter sizes, indicating that the gene deficiency did not impair fertility or fecundity. Alveolar macrophages from wild-type but not $L \mathrm{pla2^{-/ }}$ mice readily degraded radiolabeled phosphatidylcholine. A marked accumulation of phospholipids, in particular phosphatidylethanolamine and phosphatidylcholine, was found in the alveolar macrophages, the peritoneal macrophages, and the spleens of $\mathrm{Lpla2}^{-1-}$ mice. By 1 year of age, $\mathrm{Lpla2}^{-/-}$mice demonstrated marked splenomegaly and increased lung surfactant phospholipid levels. Ultrastructural examination of $\mathrm{Lpla}^{-/-}$mouse alveolar and peritoneal macrophages revealed the appearance of foam cells with lamellar inclusion bodies, a hallmark of cellular phospholipidosis. Thus, a deficiency of lysosomal phospholipase $\mathbf{A} 2$ results in foam cell formation, surfactant lipid accumulation, splenomegaly, and phospholipidosis in mice.
\end{abstract}

Previously, a novel enzyme was discovered in the lysosomal fraction of MDCK cells. The enzyme was characterized as having ceramide transacylase and phospholipase A2 activity (3). The enzyme was purified, cloned, and named lysosomal phospholipase A2 (LPLA2) (12). Characteristics of the enzyme include a pH optimum of 4.5 and calcium independence. In addition, phosphatidylcholine and phosphatidylethanolamine are preferentially favored as substrates for the phospholipase A2. The enzyme is highly homologous with lecithin cholesterol acyltransferase and is phylogenetically related to a large group of plant phospholipases (15). Most recently, the phospholipase activity was demonstrated as highly expressed in alveolar macrophages, suggesting a potential role for LPLA2 in the phospholipid catabolism of pulmonary surfactant (1). LPLA2-deficient mice were generated to further evaluate the biological function of LPLA2.

In the present study, double conditional targeted mice were generated, and the targeted gene was modified using Cre/loxP and Flp/FRT recombination systems. Lpla2-deficient mice were generated in which exon 5 of the Lpla2 gene, which encodes the lipase motif essential for Lpla2 activity, was sys-

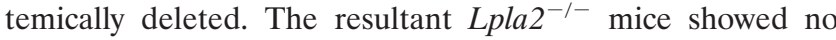
LPLA2 activity, developed normally, and were characterized by a marked accumulation of phospholipid in their alveolar macrophages, peritoneal macrophages, and spleens at an early age. Increased lung surfactant phospholipid and splenomegaly were observed in mice by 1 year of age.

* Corresponding author. Mailing address: Department of Internal Medicine, University of Michigan, Room 1560 MSRB II, 1150 West Medical Center Dr., Ann Arbor, MI 48103-0676. Phone: (734) 7630992. Fax: (734) 763-0982. E-mail: jshayman@umich.edu.

$\dagger$ Supplemental material for this article may be found at http://mcb .asm.org/.

¥ These authors contributed equally to this work.

\section{MATERIALS AND METHODS}

Reagents. Synthetic phospholipids, including 1,2-dioleloyl-sn-glycero-3-phosphorylcholine (DOPC), 1-palmitoyl-2-oleoyl-sn-glycero-3-phosphorylcholine (POPC), and 1,2-dimyristoleoyl-sn-glycero-3-phosphocholine (14:1-14:1 PC); 1,2-dipentadecanoyl-sn-glycero-3-phosphoethanolamine (15:0-15:0 PE); 1,2-dipenta-decanoyl-sn-glycero-3-phosphoglycerol (15:0-15:0 PG); 1,2-dimyristoyl-snglycero-3-phosphoserine (14:0-14:0 PS); 1-heptadecanoyl-2-hydroxyl-sn-glycero3-phos-phocholine (17:0 lysoPC); and $N$-heptadecanoyl ceramide (N17:1 Cer) were purchased from Avanti Polar Lipids, Inc. (Alabaster, AL). Deuterated palmitic acid $\left(\mathrm{d}_{4}-16: 0 \mathrm{FA}\right)$ was purchased from Cambridge Isotope Laboratories (Andover, MA). Dicetyl phosphate was purchased from Sigma (St. Louis, MO), 1-palmitoyl-2-[ $\left[{ }^{14} \mathrm{C}\right]$ oleoyl-sn-3-glycero-phosphorylcholine $(25 \mu \mathrm{Ci} / \mathrm{ml})$ was from Amersham Biosciences (Piscataway, $\mathrm{NJ}$ ), and $N$-acetyl-D-erythro-sphingosine (NAS) was from Matreya (Pleasant Gap, PA). Bicinchoninic acid protein assay reagent was obtained from Pierce Chemical (Rockford, IL).

Generation of Lpla 2 double conditional targeted mice. The genome sequence containing the Lpla2 gene was obtained from screening the Resgen CJ7 embryonic stem (ES) cell line BAC clone library (Invitrogen, Carlsbad, CA). A SmaISacI fragment of approximately 8,450 bp of the Lpla2 gene was subcloned into the pUC vector. In a previous report it was shown that the lipase motif, located within exon 5, is essential for LPLA2 enzyme activity (12). Therefore, to create the conditional null allele, the SpeI-DraI region containing exon 5 was floxed with two loxP sites and then inserted into the vector (Fig. 1A). The PGK-neo cassette flanked with two $F R T$ sites was inserted at the SpeI site in the intron between exons 4 and 5 in reverse orientation. The targeting vector was sequenced to ensure that no mutation had been introduced and then was linearized by NdeI digestion and electroporated into CJ7 ES cells. Homologous recombinant clones were obtained from G418-resistant colonies screened at a frequency of $20 \%$. The G418-resistant clones were screened by PCR using primers inside and outside the targeting construct. A correctly targeted clone was injected into C57BL/6 blastocysts. The chimeric mice were mated with C57BL/6 to obtain heterozygous mice carrying the targeted allele. Mice carrying the targeted allele were mated with $f p 1$ mice (stock no. 3800; The Jackson Laboratory) to delete the neo cassette. The conditional heterozygous mice were then mated with EIIa Cre mice of C57BL/6 background (stock no. 3724; The Jackson Laboratory) to excise the region containing exon 5 . The heterozygous mice carrying the null allele were mated to generate homozygous $(-/-)$, heterozygous $(+/-)$, and wild-type $(+/+)$ littermates of the Lpla2 null allele. Homologous recombination at the null allele was screened by PCR (Fig. 1B). Genomic DNA was extracted from the tails of the mice. The PCR primers were as follows: a, 5'-CAGGGTA GCTCACAACTCTTTG-3'; b, 5'-CAAAGCTCTGGACTGTTTTCCTGC-3'; c, 
A

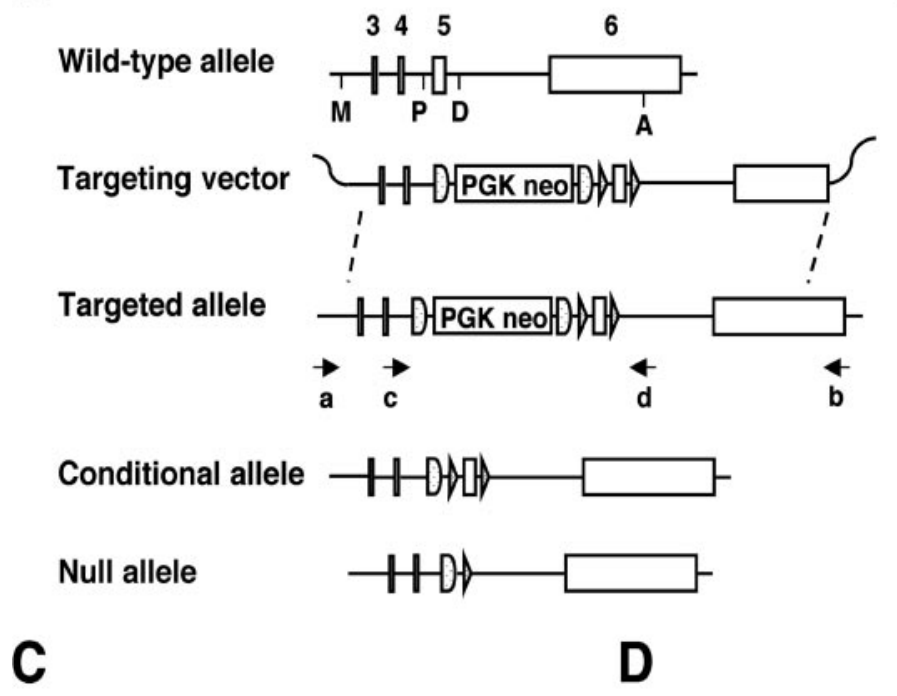

B
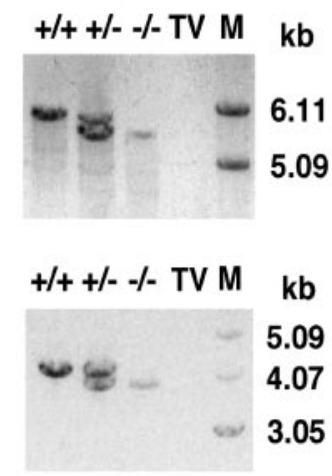

E
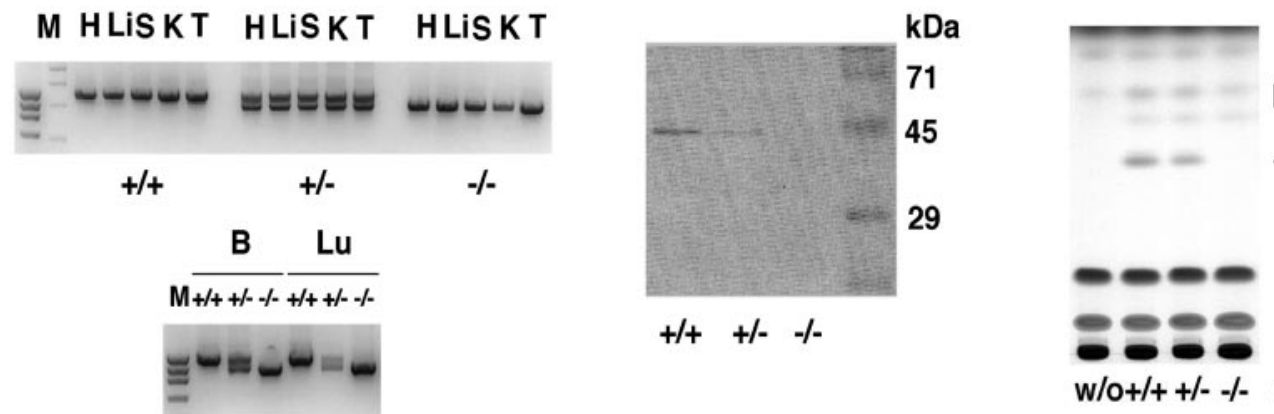

w/o+/++/- - /- Soluble Fr.

FIG. 1. A. Strategy for producing allelic series of mutations at the Lpla2 locus. The partial map of the murine Lpla2 locus is displayed. Horizontal lines and open boxes with numbers represent introns and Lpla2 exons, respectively. Vertical lines represent restriction sites: M, SmaI; P, SpeI; D, DraI; A, SacI. The Lpla2 double conditional targeting vector was designed. Shaded triangles represent loxP sites flanking the Lpla2 gene exon 5, and shaded half-circles represent FRT sites flanking the neomycin resistance cassette (PGK neo). The targeted allele was generated by homologous recombination. The primers used for PCR are shown as horizontal arrows with letters. The conditional allele was generated by Flp-mediated excision. The heterozygous mice carrying targeted alleles were mated with FLP1 transgenic mice to delete the neo cassette. The null allele was generated by Cre-mediated excision. The heterozygous mice carrying conditional alleles were mated with EIIa Cre transgenic mice to delete exon 5. B. Genotype analysis by PCR. Genomic DNA was extracted from mouse tail, and PCR was performed to evaluate homologous recombination. The primers a and $\mathrm{d}$ as well as $\mathrm{b}$ and $\mathrm{c}$ were used for upper panel and lower panel assays, respectively. TV indicates targeting vector. $\mathrm{M}$ indicates molecular marker. C. Reverse transcription-PCR assay. Total RNAs were isolated from various mouse organs and synthesized cDNA. PCR was performed using primers which are able to cover the Lpla2 coding region. M, molecular marker $\phi_{-} 174 \mathrm{RF}$ DNA/HaeIII; H, heart; Li, liver; S, spleen; K, kidney; T, thymus; B, brain; Lu, lung. D. Immunoblots of Lpla2 from the alveolar macrophages obtained from Lpla $2^{+/+}$, Lpla $^{+1-}$, and Lpla $2^{-1-}$ mice. Alveolar macrophages were isolated from mice as described in Materials and Methods, and the soluble fraction was separated by gel electrophoresis as previously described (1). A rabbit anti-LPLA2 polyclonal antibody $\left({ }^{100}\right.$ RTSRATQFPD $\left.^{109}\right)$ was used for detection. E. Transacylase activity in the soluble fraction of alveolar macrophages obtained from $\mathrm{Lpla}^{+/+}, \mathrm{Lpla2}^{+/-}$, and Lpla2 ${ }^{-/-}$mice. Each soluble fraction ( $3 \mu \mathrm{g}$ of protein) obtained from 3-month-old Lpla $^{+/+}$, Lpla $^{+/-}$, and Lpla $2^{-1-}$ mouse alveolar macrophages was incubated for $30 \mathrm{~min}$ at $37^{\circ} \mathrm{C}$ in citrate buffer, $\mathrm{pH} 4.5$, with $40 \mu \mathrm{M}$ NAS in liposomal form, and formation of 1-O-acyl-NAS was determined as described in

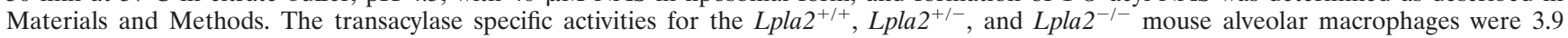
$\mu \mathrm{g} / \mathrm{min} / \mathrm{mg}$ protein, $2.08 \mu \mathrm{g} / \mathrm{min} / \mathrm{mg}$ protein, and undetected, respectively. w/o, without; Fr., fraction.

\begin{abstract}
5'-GAATTCCTAGACCCCAGCAAGAAGAATGTG-3'; and d, 5'-CCCTCCC CAGAGATGGATATTT- $3^{\prime}$. Primers a and d generated $5.8-\mathrm{kb}$ and $5.5-\mathrm{kb}$ products from a wild-type allele and a null allele by PCR, respectively. Primers b and c generated $4.1-\mathrm{kb}$ and $3.8-\mathrm{kb}$ products from a wild-type allele and a null allele by PCR, respectively. The PCR amplification employed 35 cycles with steps at $94^{\circ} \mathrm{C}$ for $30 \mathrm{~s}, 60^{\circ} \mathrm{C}$ for $30 \mathrm{~s}$, and $72^{\circ} \mathrm{C}$ for $3 \mathrm{~min}$, which was extended $20 \mathrm{~s}$ every cycle for the last 25 cycles using ExTaq DNA polymerase (Takara Bio, Shiga, Japan). The PCR products were subjected to electrophoresis, purification, and sequencing. To confirm wild-type, conditional, and null alleles, the PCR with primers c and d using rTaq polymerase (Takara Bio) employed 35 cycles with steps at $94^{\circ} \mathrm{C}$ for $30 \mathrm{~s}, 60^{\circ} \mathrm{C}$ for $30 \mathrm{~s}$, and $72^{\circ} \mathrm{C}$ for $1 \mathrm{~min}$. The product sizes were 1,212, 1,444, and 894 bp for the wild-type, conditional, and null alleles, respectively.
\end{abstract}

Reverse transcription-PCR analysis. Total RNA was isolated from each mouse organ using Trizol reagent (Invitrogen) followed by purification using an RNeasy kit (QIAGEN, Valencia, CA). The total RNA was used to synthesize cDNA with oligo(dT) ${ }_{12-18}$ primers in the SuperScript First-Strand synthesis system (Invitrogen). Primers used for PCR were 5'-ATGGATCGCCATCTC-3' (forward) and 5'-TCAAGGTTCCAGAAGCACACGTTT-3' (reverse). PCR was performed using $r$ Taq polymerase with the conditions described above. PCR products were purified and sequenced.

Isolation of mouse macrophages and tissues. All mice were housed in specificpathogen-free conditions and used at 2 to 12 months of age. After anesthesia with $\mathrm{CO}_{2}$ inhalation, the organs were isolated. For isolation of alveolar macrophages, the tracheae were cannulated and the lungs were lavaged with phos- 
phate-buffered saline (PBS) containing $0.5 \mathrm{mM}$ EDTA. Peritoneal macrophages were obtained by lavage of the peritoneal spaces with PBS containing $0.5 \mathrm{mM}$ EDTA. After being counted, cells were suspended in RPMI 1640 medium containing $1 \times$ antibiotic-antimycotic solution (Invitrogen) and plated in culture dishes, followed by incubation at $37^{\circ} \mathrm{C}$ in a humidified atmosphere of $5 \% \mathrm{CO}_{2}$ in air. Nonadherent cells were removed by washing with PBS. Under these conditions, the recovered cells were greater than $90 \%$ macrophages as measured by Wright-Giemsa and anti-CD68 staining. The University of Michigan Committee on the Use and Care of Animals approved all experiments.

Electron microscopy. Fresh tissue was minced into 1-mm cubes, and alveolar and peritoneal lavage cells were collected and then fixed by immersion in $4 \%$ glutaraldehyde, $0.1 \mathrm{M}$ sodium cacodylate buffer $(\mathrm{pH}$ 7.3). The sample was postfixed with osmium tetroxide before embedding in Epon. One-micrometer sections, stained with toluidine blue, were screened by light microscopy to select cross-sections for ultrastructural study. Thin sections were stained with uranyl acetate and lead citrate before examination with a Philips 400T transmission electron microscope. Representative photomicrographs were selected.

Preparation of cell homogenate and soluble fraction from mouse alveolar and peritoneal macrophages and tissues. For the preparation of the soluble fractions of alveolar macrophages and peritoneal macrophages, the cells were allowed to adhere to $35-\mathrm{mm}$ culture dishes, washed three times with $2 \mathrm{ml}$ of cold PBS, scraped with a small volume of PBS, and transferred into 15 -ml plastic tubes. The cells were collected by centrifugation at $800 \times g$ for $10 \mathrm{~min}$ at $4^{\circ} \mathrm{C}$ and resuspended with 0.4 to $1.0 \mathrm{ml}$ of cold $0.25 \mathrm{M}$ sucrose, $10 \mathrm{mM}$ HEPES (pH 7.4), $1 \mathrm{mM}$ EDTA. The cell suspension was disrupted five times with a probe-type sonicator for $10 \mathrm{~s}$ at $0^{\circ} \mathrm{C}$ to obtain the cellular homogenate. The homogenate was centrifuged for $1 \mathrm{~h}$ at $100,000 \times g$ at $4^{\circ} \mathrm{C}$. The resultant supernatant was passed through a $0.2-\mu \mathrm{m}$ filter and used as a soluble fraction. For the preparation of soluble fractions of mouse tissues, each organ was washed with cold PBS, weighed, and homogenized by a Potter Elvehjem homogenizer with cold $0.25 \mathrm{M}$ sucrose, 10 mM HEPES ( $\mathrm{pH}$ 7.4), 1 mM EDTA. The homogenate was centrifuged for 10 $\min$ at $600 \times g$ at $4^{\circ} \mathrm{C}$. The resultant supernatant was sonicated with a probe-type sonicator for $10 \mathrm{~s}$ five times at $0^{\circ} \mathrm{C}$ and centrifuged for $1 \mathrm{~h}$ at $100,000 \times g$ at $4^{\circ} \mathrm{C}$ The supernatant was passed through a $0.2-\mu \mathrm{m}$ filter and used as a soluble fraction.

Enzyme phospholipase A2/transacylase assay. Phospholipids, DOPC and PE, and $N$-acetylsphingosine were used in the assay system as donor and an acceptor, respectively, of an acyl group. The transacylase activity by LPLA2 was determined by analysis of 1-O-acyl- $N$-acetylsphingosine formation rate. The reaction mixture consisted of $45 \mathrm{mM}$ sodium citrate $(\mathrm{pH} 4.5), 10 \mu \mathrm{g} / \mathrm{ml}$ bovine serum albumin, and $40 \mu \mathrm{M} \mathrm{N}$-acetylsphingosine incorporated into phospholipid liposomes (DOPC/PE/dicetyl phosphate/ $N$-acetylsphingosine [5:2:1:2 molar ratio]) and soluble fractions $(0.7$ to $10 \mu \mathrm{g})$ in a total volume of $500 \mu \mathrm{l}$. The reaction was initiated by adding the soluble fraction, kept for 5 to $60 \mathrm{~min}$ at $37^{\circ} \mathrm{C}$, and terminated by adding $3 \mathrm{ml}$ of chloroform/methanol (2:1) plus $0.3 \mathrm{ml}$ of $0.9 \%$ $(\mathrm{wt} / \mathrm{vol}) \mathrm{NaCl}$. The mixture was centrifuged for $5 \mathrm{~min}$ at room temperature. The resultant lower layer was transferred into another glass tube and dried under a stream of nitrogen gas. The dried lipid dissolved in $40 \mu \mathrm{l}$ of chloroform/methanol (2:1) was applied on an high-performance thin-layer chromatography (HPTLC) plate and developed in a solvent system consisting of chloroform/acetic acid (9:1). The plate was dried and soaked in $8 \%$ (wt/vol) $\mathrm{CuSO}_{4}, 5 \mathrm{H}_{2} \mathrm{O}, 6.8 \%$ (vol/vol) $\mathrm{H}_{3} \mathrm{PO}_{4}, 32 \%$ (vol/vol) methanol. The wet plate was briefly dried with a hair dryer and charred for $15 \mathrm{~min}$ in a $150^{\circ} \mathrm{C}$ oven. The plate was scanned, and NIH-image 1.62 was used to quantify the reaction products.

The following protocol was used for the phospholipase A2 assay without $N$-acetylsphingosine as an acceptor. The reaction mixture contained $48 \mathrm{mM}$ sodium citrate ( $\mathrm{pH} 4.5), 10 \mu \mathrm{g} / \mathrm{ml}$ bovine serum albumin, liposomes $(130 \mu \mathrm{M}$ phospholipid), and $1.77 \mu \mathrm{g} / \mathrm{ml}$ of the soluble fraction obtained from $\mathrm{Lpla}^{+/+}$or Lpla $2^{-1-}$ mouse alveolar macrophages in $500 \mu \mathrm{l}$ of total volume. The liposomes consisted of 1-oleoyl-2-palmitoyl-sn-glycero-3-phosphocholine and dicetylphosphate in the molar ratio $10: 1$, with a trace of 1-palmitoyl-2-1-[ $\left.{ }^{14} \mathrm{C}\right]$ palmitoyl-L$s n$-glycero-3-phosphocholine $\left(2.8 \times 10^{5} \mathrm{cpm} /\right.$ assay $)$. The reaction was initiated by adding $20 \mu \mathrm{l}$ of each soluble fraction or sucrose buffer, kept for 15,30 , and 45 $\min$ at $37^{\circ} \mathrm{C}$, and terminated by the addition of $3 \mathrm{ml}$ of chloroform/methanol (2:1) plus $300 \mu \mathrm{l}$ of $0.9 \% \mathrm{NaCl}$. The resultant lower layer was transferred into a small glass tube and dried under a stream of nitrogen gas. The dried lipid was redissolved with chloroform/methanol (2:1) and applied to an HPLTC plate. The plate was developed in a solvent system consisting of chloroform/methanol/ pyridine (98:2:0.5). After development, the plate was dried, sprayed with ENHANCE, and exposed on X-ray film at $-80^{\circ} \mathrm{C}$ for $20 \mathrm{~h}$. In the study using lung tissue, the same reaction was initiated by the addition of $10 \mu \mathrm{g}$ of lung soluble fraction and kept for 30,60 , and $90 \mathrm{~min}$ at $37^{\circ} \mathrm{C}$.
Lipid analysis. Lipids were extracted from tissues, alveolar macrophages, peritoneal macrophages, and bronchoalveolar lavage fluid of 3-month-old mice by the partially modified method of Bligh and Dyer (5). The phospholipid content was measured by the method of Ames (4). Individual phospholipids were separated by high-performance thin-layer chromatography and quantified as described above. Disaturated phosphatidylcholine in samples was isolated by the method of Mason et al. (13). Whole-lipid extract (20 to $100 \mathrm{nmol}$ as phospholipid) was dried under a stream of nitrogen gas. The dried lipid was dissolved in $500 \mu \mathrm{l}$ of $6.2 \mathrm{mg} / \mathrm{ml}$ osmium tetraoxide in carbon tetrachloride and incubated for $15 \mathrm{~min}$ at room temperature. The reaction mixture was dried under a stream of nitrogen gas, redissolved in $500 \mu \mathrm{l}$ of chloroform/methanol (20:1, vol/vol), and applied to an alumina column ( $0.6 \mathrm{~g}$ of activated neutral aluminum oxide, 150 mesh) preequilibrated with chloroform/methanol (20:1, vol/vol). The column was washed with $8 \mathrm{ml}$ of chloroform/methanol (20:1, vol/vol). Disaturated phosphatidylcholine was eluted with $4 \mathrm{ml}$ of chloroform/methanol/7 M ammonium hydroxide $(70: 30: 2, \mathrm{vol} / \mathrm{vol})$, and the eluted fraction was dried under a stream of nitrogen gas. Phosphate content was determined by the method of Ames (4).

For electrospray ionization/mass spectrometry (ESI/MS), lipid extraction from alveolar macrophage preparations ( 0.1 to $0.5 \mathrm{mg}$ of proteins) was performed using a modified method of Bligh and Dyer as previously described in detail (11). Briefly, internal standards, including 14:0-14:0 phosphatidylserine $(8.0 \mathrm{nmol} / \mathrm{mg}$ protein), 15:0-15:0 phosphatidylglycerol (6 nmol/mg protein), 15:0-15:0 PE (13 $\mathrm{nmol} / \mathrm{mg}$ protein), 14:1-14:1 PC (20 nmol/mg protein), 17:0 lysoPC (2 nmol/mg protein), N17:1 ceramide $\left(0.24 \mathrm{nmol} / \mathrm{mg}\right.$ protein), and $\mathrm{d}_{4-1} 16: 0$ fatty acid (12 $\mathrm{nmol} / \mathrm{mg}$ protein), were added to each individual sample based on protein concentration. Lipids from each sample were extracted against $2 \mathrm{ml}$ of $50 \mathrm{mM} \mathrm{LiCl}$ twice, back extracted against $2 \mathrm{ml}$ of $10 \mathrm{mM} \mathrm{LiCl}$ twice, filtered with a $0.2-\mu \mathrm{m}$ polytetrafluoroethylene syringe filter, and finally stored in chloroform/methanol $(1: 1, \mathrm{vol} / \mathrm{vol})$ at a concentration of $600 \mu \mathrm{l} / \mathrm{mg}$ protein. The lipid extracts were finally flushed with nitrogen, capped, and stored at $-20^{\circ} \mathrm{C}$ for ESI/MS analyses (typically within 1 week). Each lipid solution was further diluted approximately 10 -fold just prior to infusion and lipid analysis. To this diluted lipid solution, $\mathrm{LiOH}$ (50 nmol/mg of protein) was added just prior to performing further lipid analyses in both negative- and positive-ion modes.

ESI/MS analyses were performed utilizing a triple-quadrupole mass spectrometer (ThermoElectron TSQ Quantum Ultra, San Jose, CA) equipped with an electrospray ion source as described previously (11). Typically, a 1-min period of signal averaging in the profile mode was employed for each MS spectrum, and a 1- to 2-min period of signal averaging for each MS/MS spectrum was used. Global analyses of lipid extracts were performed by shotgun lipidomics as described previously $(9,10)$. Quantitation of each individual molecular species of lipid classes were performed using a two-step process, as described in detail previously $(8,9)$.

Degradation of 1-palmitoyl-2-[ $\left[{ }^{14} \mathrm{C}\right]$ oleoyl-sn-glycero-3-phosphorylcholine (POPC) by alveolar macrophages. Alveolar macrophages $\left(1.3 \times 10^{6}\right.$ cells $)$ obtained from 3- to 5-month-old $\mathrm{Lpla}^{+/+}$and $\mathrm{Lpla}^{-/-}$mice were seeded into a 35-mm dish containing $2 \mathrm{ml}$ of RPMI 1640 medium (Invitrogen) containing $1 \times$ antibiotic-antimycotic and followed by incubation at $37^{\circ} \mathrm{C}$ in a humidified atmosphere of $5 \% \mathrm{CO}_{2}$ in air. After $90 \mathrm{~min}$, nonadherent cells were removed by washing with PBS. The adherent cells were incubated with $2.1 \mathrm{ml}$ of RPMI 1640 medium containing $320 \mu \mathrm{M}(0.25 \mu \mathrm{Ci} / \mathrm{ml}){ }^{14} \mathrm{C}$-labeled POPC in liposomes consisting of POPC/dicetyl phosphate (10:1 molar ratio) for $4 \mathrm{~h}$ at $37^{\circ} \mathrm{C}$. After the incubation, the cells were washed three times with $2 \mathrm{ml}$ of cold PBS and fixed with $1 \mathrm{ml}$ of cold methanol. The fixed cells were scraped and transferred into a glass tube. An additional $1 \mathrm{ml}$ of methanol was used to recover the remaining cells in the dish. The cell suspension was mixed with $1 \mathrm{ml}$ chloroform plus $0.8 \mathrm{ml}$ of $0.9 \% \mathrm{NaCl}$ and sonicated in a water bath sonicator briefly and kept for $1 \mathrm{~h}$ at room temperature. The mixture was centrifuged for $30 \mathrm{~min}$ at 2,000 $\times g$ at room temperature, and the supernatant was transferred into a long glass tube. The supernatant was mixed and vortexed with $3 \mathrm{ml}$ of chloroform plus $0.8 \mathrm{ml}$ of $0.9 \%$ $\mathrm{NaCl}$ and centrifuged for $5 \mathrm{~min}$ at $800 \times g$. The lower layer was washed with 2 $\mathrm{ml}$ of methanol plus $1.6 \mathrm{ml}$ of $0.9 \% \mathrm{NaCl}$, centrifuged for $5 \mathrm{~min}$ at $800 \times g$, and washed again with $2 \mathrm{ml}$ of methanol plus $1.6 \mathrm{ml}$ of water. The resultant lower layer was transferred into another glass tube and dried under a stream of nitrogen gas. The dried lipid was dissolved in $100 \mu l$ of chloroform/methanol $(2: 1, \mathrm{vol} / \mathrm{vol})$. Half of the lipid extract was applied to an HPTLC plate and developed in a solvent system consisting of chloroform/acetic acid (9:1, vol/vol) or chloroform $/ \mathrm{methanol} /$ water $(60: 35: 8, \mathrm{vol} / \mathrm{vol} / \mathrm{vol})$. After development, the plate was dried, sprayed with ENHANCE, and exposed on X-ray film at $-80^{\circ} \mathrm{C}$ for 4 days.

Nucleotide sequence accession number. The genome sequence containing the Lpla2 gene has been submitted to GenBank under accession number AY179884. 


\section{RESULTS}

Generation of LPLA2-deficient mice. To create Lpla2 null mice, a targeting vector was designed and constructed containing two loxP sites and two FRT sites with a PGK-neo cassette placed between the FRT sites for modification by use of Cre/ loxP and Flp/FRT recombination systems (Fig. 1A). Exon 5, which encodes the lipase motif essential for Lpla2 activity, was floxed with two loxP sites and then inserted into the vector. CJ7 ES cells were electroporated with the linearized targeting vector. Homologous recombinant clones were obtained from G418-resistant colonies screened at a frequency of $20 \%$. A correctly targeted clone was injected into C57BL/6 blastocysts. The chimeric mice were mated with $\mathrm{C} 57 \mathrm{BL} / 6$ mice to obtain heterozygous mice carrying the targeted allele.

Mice carrying the targeted allele were found to be normal and fertile. However, homozygous offspring from heterozygous pairs showed a modest reduction of Lpla2 activity in the soluble fraction of brain (data not shown). This finding suggested that the neo cassette inclusion affected Lpla2 expression. flp1 transgenic mice express FLP recombinase in the early embryo under the control of the human $\beta$-actin promoter. Mice with the targeted allele were mated with flp1 transgenic mice to delete the neo cassette. The allele in which the neo cassette was deleted by using an Flp/FRT recombination system is termed the "conditional allele." Mice carrying the conditional allele were normal in appearance and were fertile. The Lpla2 enzyme activity in the homozygous mice carrying the conditional allele was found to be the same as that of wild-type mice (data not shown). EIIa Cre transgenic mice express Cre recombinase in the one-cell zygote stage of embryo development under the control of the adenovirus EIIa promoter. Heterozygous mice carrying the conditional allele were mated with EIIa Cre transgenic mice to excise the region containing exon 5 . The resultant heterozygous mice carrying the null allele were mated

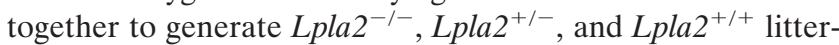
mates. Homologous recombination at the null allele was screened by PCR (Fig. 1B). The predicted product from the deletion of the loxP site flanking region was detected in both

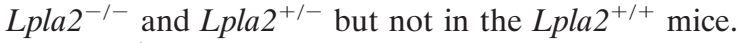

Lpla $2^{+/-}$mice were viable and fertile. They produced an average of 8.7 pups per litter with a normal Mendelian frequency, indicating no selective fetal or neonatal loss of homozygous pups. Survival of the Lpla ${ }^{-1-}$ mice was normal. Lpla $2^{-/-}$mating pairs gave normal litter sizes (8.5 pups per litter), indicating that the gene deficiency did not grossly impair fertility or fecundity. Screening of Lpla2 mRNA expression in seven organs from Lpla2 $2^{-1-}$ mice demonstrated the deletion of exon 5 in each organ (Fig. 1C), indicating that the deletion was systemic.

An immunoblot was performed on the protein extracts from

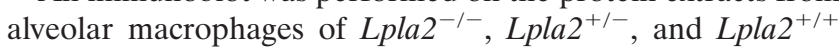
mice using a previously generated rabbit polyclonal antibody raised to mouse Lpla2 peptide $\left({ }^{100}\right.$ RTSRATQFPD $\left.^{109}\right)$ (1). A single band at a molecular mass of ca. $44 \mathrm{kDa}$ was observed in blots from ppla2 $^{+/+}$and Lpla2 $2^{+/-}$macrophages. However, no protein was detected from Lpla2 $2^{-1-}$ alveolar macrophages (Fig. 1D). The Lpla2 enzyme activities were also compared among genotypes. The transacylase activity, as measured by the formation of 1-O-acyl- $N$-acetylsphingosine, was absent in Lpla2 $2^{-1-}$ mouse alveolar macrophages (Fig. 1E). The transacylase activity from Lpla2 ${ }^{+/-}$mouse alveolar macrophages was approximately $50 \%$ of that of the Lpla2 ${ }^{+/+}$mouse alveolar macrophages. The deficiency of the enzyme activity in the soluble fraction of the Lpla $2^{-1-}$ mouse was also observed in other cells and tissues, including peritoneal macrophages, heart, lung, liver, spleen, kidney, thymus, and brain (data not shown).

Phospholipid degradation in alveolar macrophages. Many classes of phospholipase A2 exist (17). On the one hand, the absence of ceramide transacylase activity in alveolar macrophages might not necessarily mean that cellular phospholipase A2 activity would be impaired as well. On the other hand, Lpla2 is very highly expressed in alveolar macrophages and might represent the major phospholipase A2 activity. Therefore, the degradation of PC was more extensively evaluated in the mouse alveolar macrophages. A choice of substrate was required. When previously studied, Lpla2 was observed to recognize 1,2-dipalmitoyl-sn-glycero-3-phosphorylcholine (DPPC), a major component of pulmonary surfactant lipid, when presented as a substrate in DOPC/DPPC liposomes (1). However, Lpla2 demonstrated greater activity toward DOPC than DPPC. Furthermore, DPPC led to a reduction of the enzyme activity on DOPC in DOPC/DPPC liposomes. These results suggested that unsaturated phospholipids are better substrates than saturated phospholipids and may provide a preferable environment in the Lpla2 reaction.

The transfer of oleic acid to $N$-acetyl-sphingosine and the release of oleic acid from POPC by the soluble fraction obtained from $\mathrm{Lpla}^{+/+}$mouse alveolar macrophages were observed when POPC/dicetyl phosphate $/ N$-acetyl-sphingosine liposomes were used (Fig. 2A). The transacylase activity in the POPC liposome system was comparable to that observed with the DOPC/dicetyl phosphate/ $N$-acetyl-sphingosine liposome system. These results were further evaluated with the use of alveolar macrophages and radiolabeled POPC. Using 1-palmitoyl-2-[ $\left.{ }^{14} \mathrm{C}\right]$ oleoyl-sn-glycero-3-phosphorylcholine, the phospholipase A2 activity was compared between the lungs and

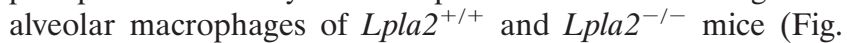
2B). When assayed at $\mathrm{pH} 4.5$, the phospholipase A2 activity in the wild-type lung was $1.10 \mathrm{nmol} / \mathrm{min} / \mathrm{mg}$ protein but was only $0.072 \mathrm{nmol} / \mathrm{min} / \mathrm{mg}$ protein in the Lpla2 null mice. The alveolar macrophage activity was $18.6 \mathrm{nmol} / \mathrm{min} / \mathrm{mg}$ protein versus $0.43 \mathrm{nmol} / \mathrm{min} / \mathrm{mg}$ protein in the wild-type and knockout mice, respectively. The higher specific activity of Lpla2 in the alveolar macrophages compared to that of the whole lung is consistent with the prior observation reported for Lpla2 assayed as ceramide transacylation (1).

The products of the phospholipase $\mathrm{A} 2$ reaction were further evaluated. The radioactive oleic acid released from POPC was readily detected in the lipid extract obtained from the Lpla $2^{+/+}$mouse alveolar macrophages treated with 1-palmitoyl-2-[ $\left[{ }^{14} \mathrm{C}\right]$ oleoyl-sn-glycero-3-phosphorylcholine/dicethyl phosphate liposomes (Fig. 2C). On the contrary, there was no radioactive oleic acid detected in the lipid extract obtained from the Lpla2 $2^{-/-}$mouse alveolar macrophages treated with ${ }^{14} \mathrm{C}$ labeled POPC liposomes. The total radioactivity found in the lipid extract, obtained from the Lpla2 $2^{-1-}$ mouse alveolar macrophages, was approximately one-half of the amount from the Lpla $2^{+/+}$mouse macrophages. The radioactivity of oleic acid 
A
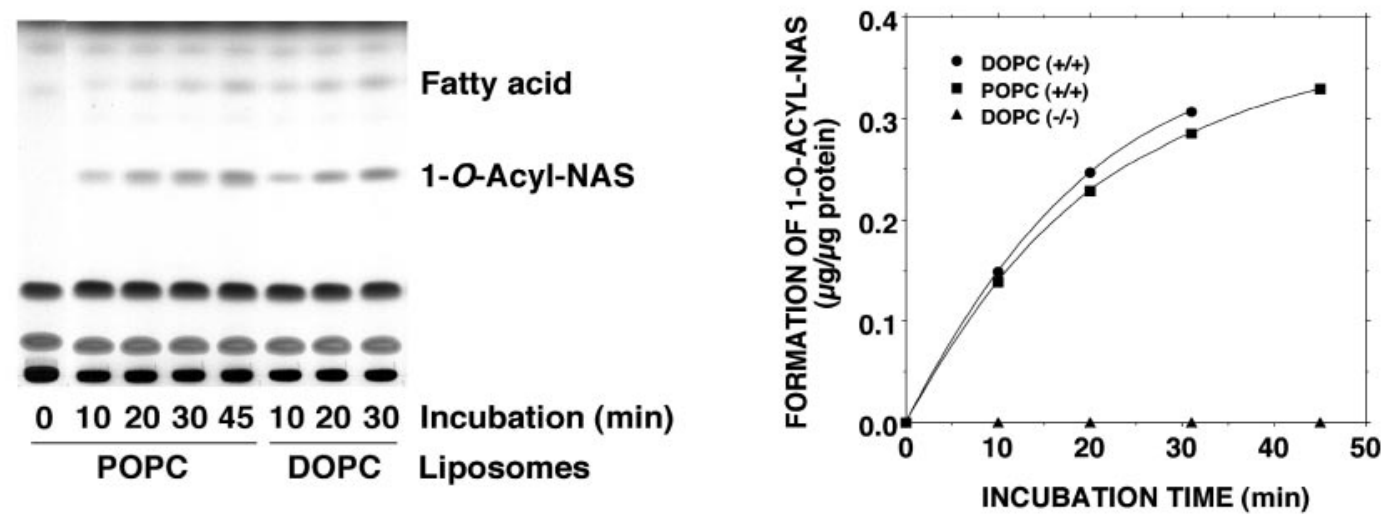

B
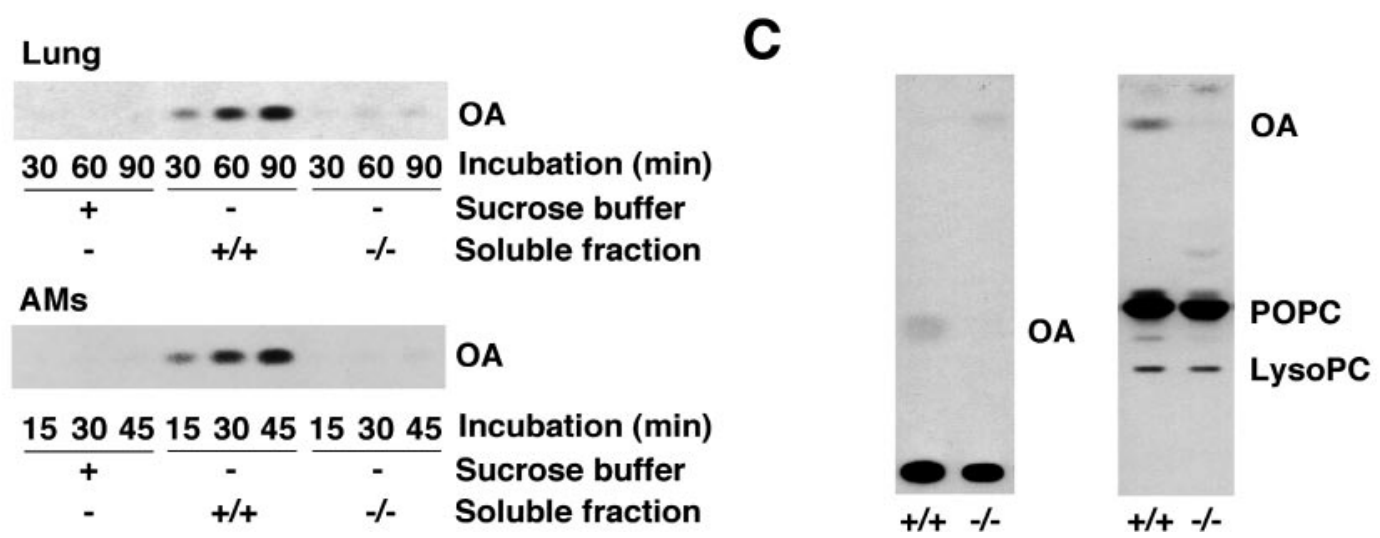

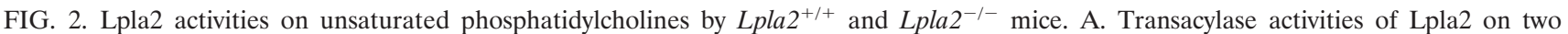
different phosphatidylcholines. The soluble fraction $\left(2 \mu \mathrm{g}\right.$ of protein) obtained from 3 -month-old $L$ pla $2^{+/+}$mice was incubated for a suitable time period at $37^{\circ} \mathrm{C}$ in citrate buffer, $\mathrm{pH} 4.5$, with $40 \mu \mathrm{M}$ NAS incorporated into phospholipid liposomes (DOPC or POPC/dicetyl phosphate/NAS [7:1:2 molar ratio]), and formation of 1-O-oleoyl-NAS was determined as described in Materials and Methods. The left panel shows the TLC. The time-dependent formation of 1-O-oleoyl-NAS from DOPC or POPC/dicetyl phosphate/NAS liposomes by the soluble fraction in $L p l a 2^{+/+}$and Lpla $2^{-l-}$ mice. The experiment is representative of three experiments with comparable results. (B) Comparison of phospholipase A2 activities in the lungs and alveolar macrophages of Lpla2 $2^{+/+}$and $\mathrm{Lpla}^{-/-}$mice. Phospholipase A2 activities were measured as described in Materials and Methods using 1-palmitoyl-2-[ $\left.{ }^{14} \mathrm{C}\right]$ oleoyl-sn-glycero-3-phosphorylcholine. OA denotes oleic acid. C. Degradation of 1-palmitoyl-2-[ $\left[{ }^{14} \mathrm{C}\right]$ oleoyl-snglycero-3-phosphorylcholine by alveolar macrophages. Alveolar macrophages $\left(1.3 \times 10^{6}\right.$ cells $)$ obtained from 3-month-old Lpla $2^{+/+}$and Lpla $^{-/-}$ mice were incubated with ${ }^{14} \mathrm{C}$-labeled POPC/dicetyl phosphate $\left(10: 1 \mathrm{molar}\right.$ ratio) liposomes for $4 \mathrm{~h}$ at $37^{\circ} \mathrm{C}$. After the incubation, the cellular lipid was extracted as described in Materials and Methods. Lipid extract was applied to an HPTLC and developed in a solvent system consisting of chloroform/acetic acid (9:1) (left) or chloroform/methanol/water (60:35:8) (right). After the development, the plate sprayed with ENHANCE was exposed on an X-ray film at $-80^{\circ} \mathrm{C}$. LysoPC indicates lysophosphatidylcholine. AMs, alveolar macrophages.

recovered from the TLC plate was $260 \mathrm{cpm}$ and $50 \mathrm{cpm}$ for Lpla $2^{+/+}$and Lpla2 $2^{-/-}$mouse macrophages, respectively (Fig. 2C). Additionally, the released radioactive oleic acid was comparably low (40 cpm on the TLC plate) when the ${ }^{14} \mathrm{C}$-labeled POPC liposomes were incubated with the cultured medium without alveolar macrophages. Thus, 10 times less radioactive oleic acid was released from the Lpla $2^{-1-}$ mouse alveolar

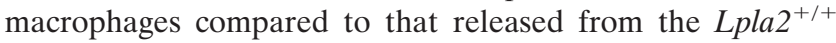
mouse macrophages. Therefore, most of the oleic acid released from POPC in the L $p l a 2^{+/+}$mouse alveolar macrophages was due to Lpla2 activity and not an alternative phospholipase A2.

Interestingly, the radioactive lysoPC was detected in Lpla2 $2^{+/+}$and $L$ pla $2^{-/-}$alveolar macrophages. This metabolite, labeled in the $s n-2$ position, is produced by phospholipase A1. The radioactivity of lysoPC was $150 \mathrm{cpm}$ and $100 \mathrm{cpm}$, respectively, for Lpla $^{+/+}$and Lpla $2^{-1-}$ mouse alveolar macrophages. These results indicate that the degradation of phos- pholipid in Lpla $^{-1-}$ mouse alveolar macrophages is most greatly impaired due to a lack of phospholipase A2 activity.

Phospholipid accumulation in the Lpla2 ${ }^{-1-}$ mouse. The phospholipid content and profile in alveolar and peritoneal macrophages and other tissues of 3-month-old Lpla2 ${ }^{+/+}$and Lpla $2^{-1-}$ mice were next examined. The total phospholipid

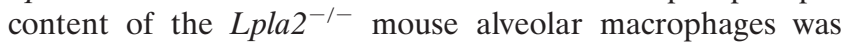
more than two times higher than that of the Lpla $2^{+/+}$mouse alveolar macrophages. Thin-layer chromatography of the lipid extract of the alveolar macrophages showed a marked accumulation of both PE and PC in the Lpla2 ${ }^{-1-}$ mouse (see the supplemental material). PE and PC levels were four times and two times higher by scanning in the pla2 $^{-/-}$versus Lpla2 ${ }^{+/+}$ mouse cells, respectively. Phosphatidylserine, phosphatidylinositol, and sphingomyelin levels were no different, consistent with the known specificity of Lpla2 for PC and PE. The total phospholipid content in the Lpla2 $2^{-/-}$peritoneal macrophages 
TABLE 1. ESI/MS analysis of alveolar macrophage lipids from 1-year-old mice

\begin{tabular}{|c|c|c|}
\hline \multirow{2}{*}{ Lipid } & \multicolumn{2}{|c|}{$\begin{array}{c}\text { Lipid level }{ }^{a}(\mathrm{nmol} / \mathrm{mg} \text { protein) } \\
\text { by phenotype }\end{array}$} \\
\hline & Lpla $2^{+/+}$ & Lpla $2^{-/-}$ \\
\hline Phosphatidylcholine & 283 & 538 \\
\hline 16:0 Phosphatidylcholine ${ }^{b}$ & 184 & 374 \\
\hline Lysophosphatidylcholine & 1.2 & 2.3 \\
\hline Phosphatidylethanolamine & 250 & 524 \\
\hline $\begin{array}{l}\text { Plasmalogen } \\
\text { phosphatidylethanolamine }{ }^{c}\end{array}$ & 173 & 414 \\
\hline Sphingomyelin & 87.4 & 76.0 \\
\hline Phosphatidic acid & 0.74 & 0.26 \\
\hline Phosphatidylglycerol & 79.8 & 129.0 \\
\hline Ceramide & 1.87 & 2.24 \\
\hline Free fatty acid & 124 & 155 \\
\hline
\end{tabular}

${ }^{a}$ Lipid levels are derived from pooled samples of six mice (three male and three female) from each group. 16:0 designates the presence of palmitoyl containing phosphatidylcholine.

${ }^{b}$ Percent 16:0 PC for Lpla2 ${ }^{+/+}$mice, 65.0; for $\mathrm{Lpla}^{-/-}$mice, 69.6.

${ }^{c}$ Percent plasmalogen phosphatidyl-ethanolamine for Lpla2 ${ }^{+/+}$mice, 69.2 ; for Lpla2 $2^{-1-}$ mice, 78.9.

(305 nmol of phospholipid/mg of protein) was $40 \%$ higher than that of the Lpla2 ${ }^{+/+}$peritoneal macrophages $(223 \mathrm{nmol}$ of phospholipid/mg of protein). A similar change in phospholipid profile was observed in the Lpla $2^{-1-}$ peritoneal macrophages.

ESI/MS analysis was used to quantify the lipid content of the Lpla2 $^{+/+}$and L $p l a 2^{-/-}$alveolar macrophages. Alveolar macrophages were isolated from 12-month-old mice, and internal standards consisting of 14:0-14:0 phosphatidylserine, 15:0-15:0 phosphatidylglycerol, 15:0-15:0 phosphatidylethanolamine, 14:1-14:1 phosphatidylcholine, 17:0 lysophosphatidylcholine, N17:1 ceramide, and $d_{4}-16: 0$ fatty acid were added to each individual sample based on protein concentration. Marked increases in PC and PE were detected in the null mouse macrophages (Table 1; also see the supplemental material). By contrast, no increase in sphingomyelin or phosphatidic acid was measured. Lysophosphatidylcholine content increased in the null mouse macrophages. However, the total lysophosphatidylcholine concentration was less than $1 \%$ of that of phosphatidylcholine. In wild-type mouse macrophages, $65 \%$ of the phosphatidylcholine had one or more fatty acids consisting of the 16:0 palmitic acid. Null mice demonstrated a fractional accumulation of saturated species of PC that was proportionate to that found in the wild-type cells (see the supplemental material). These data are consistent with the recognition of saturated species of phosphatidylcholine by Lpla2.

Histologic analysis of alveolar and peritoneal macrophages. Histology was obtained on the lung and major organs of 1-year-old wild-type and null mice. Two marked changes were observed by light microscopy of the lungs. First, alveolar macrophages were present in greater numbers and were larger in size. Second, a mononuclear cell infiltrate was observed in association with both airways and blood vessels (Fig. 3A and B).

Electron microscopy was performed on alveolar and peritoneal macrophages obtained from 3-month-old Lpla2 ${ }^{-1-}$ and
Lpla $2^{+/+}$mice to confirm the presence of phospholipidosis. The alveolar macrophages from the Lpla $2^{-/-}$mice were markedly larger than those from the Lpla $2^{+/+}$mice. Numerous lamellar inclusion bodies, indicative of cellular phospholipidosis, were observed in the Lpla2 ${ }^{-1-}$ mouse alveolar macrophages (Fig. 4B). However, such lamellar inclusion bodies were only rarely present in the Lpla2 ${ }^{+/+}$cells (Fig. 4A). A similar but less robust change was also observed in the peritoneal macrophages (Fig. 4C and 4D). The increase in phospholipid accumulation corresponds to the presence of lamellar inclusions and cellular phospholipidosis.

The phospholipid content of the mouse lung and lavage fluid was measured to ascertain if the development of alveolar foam cells was associated with an increase in total phospholipid content (Table 2). No significant change in total lung phospho-

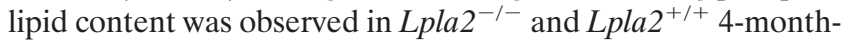
old mice. However, significant increases in both lung and lavage fluid phospholipid levels was seen in 12-month-old mice (Table 2). When the levels of disaturated PC content were measured, an increase that was proportionate to total phospholipid levels was observed in both the Lpla $2^{-/-}$mouse lung and lavage fluid.

There was no significant difference in body and organ weights between the Lpla 2 genotypes at 4 months of age. A routine histological survey of their organs, including the hearts, livers, kidneys, brains, and spleen, by hematoxylin and eosin staining showed no gross differences between wild-type and homozygous mice at 4 and 12 months of age (data not shown). However, periodic acid-schiff staining of the organs revealed the presence of foam cells throughout these organs in the homozygous null mice that was most apparent in the spleens of the 1-year-old mice (Fig. 3C and D). By 12 months of age, however, significant splenomegaly was observed in the Lpla $2^{-/-}$ mice (Fig. 5A). A greater than fourfold increase in spleen weight was observed. Phospholipid analysis revealed that the increase in phospholipid was primarily due to changes in phosphatidylcholine and phosphatidylethanolamine, consistent with the known substrate specificity of LPLA2 (Fig. 5B and C).

\section{DISCUSSION}

We successfully generated Lpla2 $2^{-1-}$ mice using a double conditional targeting system. Lpla2 $2^{-1-}$ mice generated by the systemic deletion of exon 5 of the Lpla 2 gene, which encodes the lipase motif essential for lysosomal phospholipase A2 activity, were healthy at birth and fertile. Lpla2 $2^{-/-}$mice showed no systemic lysosomal phospholipase A2 activity and a characteristic accumulation of PE and PC in alveolar macrophages, peritoneal macrophages, and spleen. A similar trend in the phospholipid profile was also observed in tissues such as liver and lung but with less accumulation. The selective accumulation of PE and PC in Lpla2 ${ }^{-/-}$mice is consistent with the previously reported substrate specificity of Lpla2. Both phospholipids are preferred substrates of Lpla2 (2). Electron microscopy revealed the presence of excessive lamellar inclusion bodies in Lpla2 ${ }^{-1-}$ alveolar and peritoneal macrophages. This foam cell phenotype is characteristic of cellular phospholipidosis (6).

Phospholipidosis is a generalized condition observed in both animals and humans that is characterized by the appearance of 

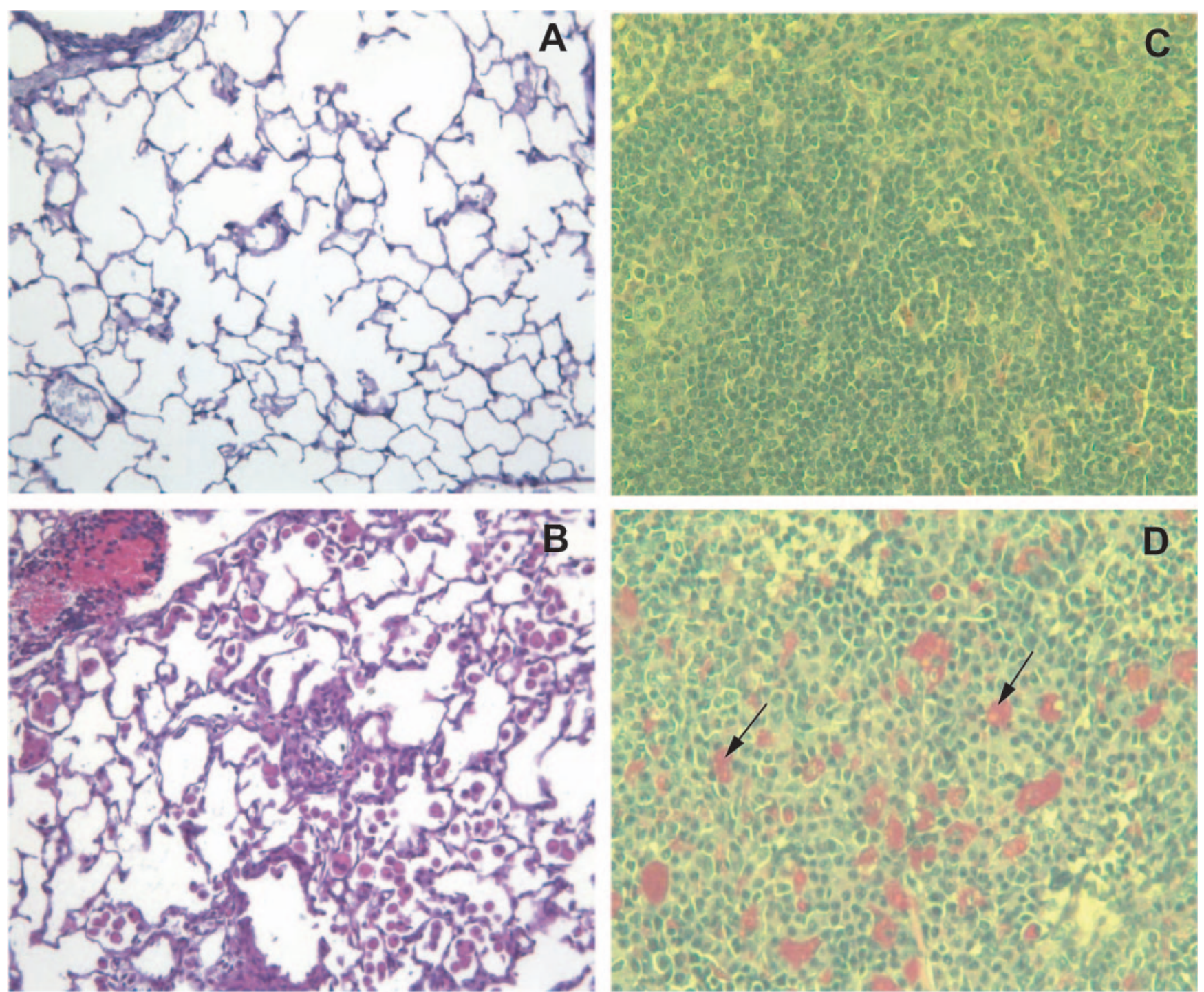

FIG. 3. Light microscopy of tissues from 1-year-old $L p l a 2^{+/+}$and $L p l a 2^{-/-}$mice. Panels A and B represent PAS staining of formalin-fixed inflated lungs and of spleens from 1-year-old wild-type and $L p l a 2^{-} /^{-}$mice, respectively. The histology is noteworthy for increased numbers of enlarged alveolar macrophages, as denoted by the arrows in the air spaces of the null mice and a mononuclear infiltrate surrounding the small airways and arteries. Panels C and D represent PAS staining from the spleens of 1-year-old wild-type and Lpla2 ${ }^{-1-}$ mice, respectively. PAS-positive macrophages are denoted by the arrows.

concentric lamellar bodies within cells and the intralysosomal accumulation of phospholipids. Phospholipidosis occurs in a variety of clinical settings. Phospholipidosis may be associated with the exposure to xenobiotics. Drugs and their metabolites that induce cellular phospholipid accumulation fall into many different classes, including antiarrhythmics, antipsychotics, antibiotics, and cholesterol-lowering agents. However, these drugs share a common physiochemical structure that includes a hydrophobic ring structure and hydrophilic side chain with a charged cationic amine group (7). Phospholipidosis may also occur in response to environmental exposures such as silica (14). Finally, phospholipidosis is often used synonymously with the term pulmonary alveolar proteinosis to describe the congenital or acquired disease associated with impaired surfactant catabolism (18). Patients suffering from pulmonary alveolar proteinosis present differently from those with drug-induced phospholipidosis. Pulmonary alveolar proteinosis is characterized by a marked accumulation of surfactant lipid; drug-induced phospholipidosis is characterized by secondary inflammatory changes and long-term fibrosis. The consequences of chronic exposure to cationic amphiphilic drugs are poorly understood, in large part due to the absence of a suitable animal model for long-term evaluation (16). In particular, the relationship between the short-term development of lysosomal phospholipid accumulation and long-term inflammation and fibrosis has not been well studied. The Lpla2 knockout mouse is a potentially useful model for elucidating this relationship.

Pulmonary alveolar proteinosis may also be associated with the absence of functional surfactant protein B or loss of granulocyte-macrophage colony-stimulating factor (GM-CSF) ac- 

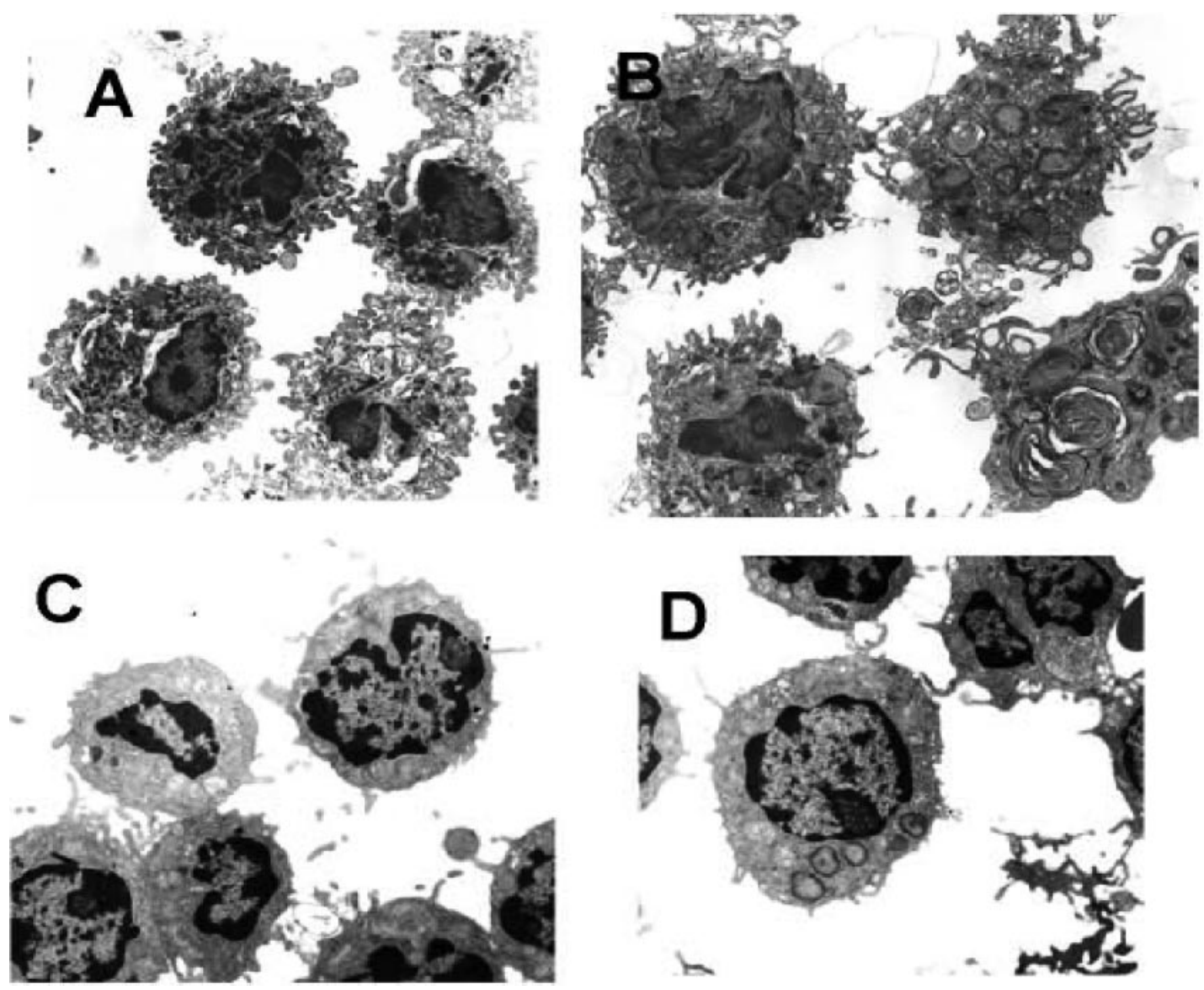

FIG. 4. Electron micrographs of alveolar macrophages (A and B) and peritoneal macrophages (C and D) obtained from 3-month-old $L$ pla $2^{+/+}$

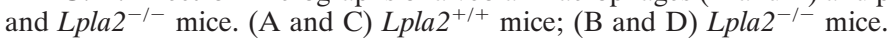

tivity (18). Although the latter is an important factor in alveolar macrophage differentiation, the relationship between loss of GM-CSF and impaired catabolism of surfactant phospholipids is not well understood. Three histological features are observed in the lungs of the GM-CSF knockout mouse. These

TABLE 2. Protein and phospholipid content of ppla2 $^{-/-}$and Lpla $2^{+/+}$mouse lung and bronchoalveolar lavage fluid

\begin{tabular}{|c|c|c|}
\hline Measurement & Lpla $^{+/+}$ & Lpla $2^{-1-a}$ \\
\hline \multicolumn{3}{|c|}{$\begin{array}{l}\text { Total protein }(\mathrm{mg} / \mathrm{kg} \text { of } \\
\text { mouse wt) }\end{array}$} \\
\hline Tissue & $448.2 \pm 12.9$ & $525.9 \pm 52.8^{*}$ \\
\hline Lavage fluid & $16.4 \pm 2.6$ & $16.1 \pm 7.5$ \\
\hline \multicolumn{3}{|c|}{$\begin{array}{l}\text { Total phospholipid } \\
\qquad(\mu \mathrm{mol} / \mathrm{kg} \text { mouse } \mathrm{wt})\end{array}$} \\
\hline Tissue & $118.9 \pm 8.8$ & $155.4 \pm 14.9^{*}$ \\
\hline Lavage fluid & $16.2 \pm 1.5$ & $21.6 \pm 1.2^{* *}$ \\
\hline \multicolumn{3}{|c|}{$\begin{array}{l}\text { Total disaturated PC } \\
\qquad(\mu \mathrm{mol} / \mathrm{kg} \text { mouse } \mathrm{wt})\end{array}$} \\
\hline Tissue & $22.7 \pm 2.2$ & $35.4 \pm 3.3^{* *}$ \\
\hline Lavage fluid & $8.3 \pm 0.7$ & $11.2 \pm 0.7^{* *}$ \\
\hline Total & $31.0 \pm 2.9$ & $46.6 \pm 4.0^{* *}$ \\
\hline
\end{tabular}

include the accumulation of surfactant in the airspaces, the development of a foam cell phenotype by alveolar macrophages, and a peribronchial and perivascular inflammation. Two of these findings, the foam cell phenotype and inflammation, are prominently found in the $\mathrm{Lpla}^{-} /^{-}$mouse. Although increased surfactant phospholipid could be detected in 1-yearold Lpla $2^{-1-}$ mice, this was less robust a finding than that observed in the GM-CSF knockout mouse. In prior work where Lpla2 was found to be highly expressed in alveolar macrophages, the GM-CSF knockout mouse was found to have limited expression of Lpla2, and a GM-CSF transgenic mouse was found to have increased expression of Lpla2 (1). The present study is also consistent with the possibility that Lpla2 mediates at least some of the GM-CSF-dependent changes observed in the lung.

An additional finding, not reported in the GM-CSF knockout mouse, was the presence of splenomegaly. This finding is consistent with that observed in another disorder of foam cell formation, Gaucher disease. The basis for the splenomegaly is unknown, but in a manner similar to Gaucher disease, it appears to be the result of secondary growth and not from the increase in lipid mass per se. Like Gaucher disease, this finding may be reflective of the role of the splenic macrophage in the clearance of senescent erythrocytes. The Lpla2 null mouse may 
A

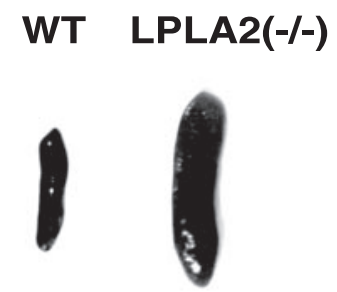

$1 \mathrm{~cm}$

B

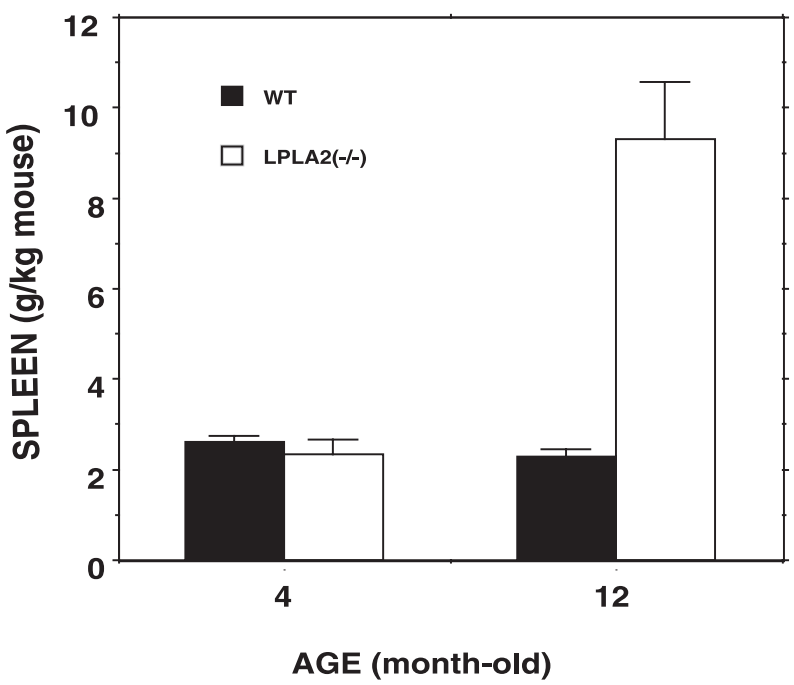

be a useful tool for probing the mechanism behind the lipidinduced organomegaly.

In addition to the increased accumulation of surfactant phospholipid in 1-year-old mice, including the accumulation of disaturated PC, further confirmation for a role for Lpla2 in surfactant degradation was based on the use of ESI/MS analysis of macrophages isolated from Lpla2 wild-type and null mice. These analyses revealed that of the measured lipids, PC and PE were most directly affected by the loss of Lpla2 activity. Those species of PC containing saturated fatty acids, most notably palmitate, as well as those with diacylglyceryl, plasmenyl, and plasmanyl linkages increased comparably in the absence of the acidic phospholipase A2 activity. These data suggest that Lpla2 does not discriminate among PCs with different aliphatic chains. By contrast, sphingomyelin and phosphatidic acid levels were not increased, consistent with the known substrate specificity of Lpla2.

A small change in ceramide content was observed. Lpla2 was originally identified as a 1-O-acylceramide synthase (3). This increase in ceramide may reflect the loss of this activity. However, the physiological role of Lpla2 as a regulator of ceramide metabolism remains to be clarified and is not obvious from the present study. Nevertheless, Lpla2 activity was measured in the wild-type and knockout mice using both ceramide and water as acceptors for the enzyme activity. By assaying Lpla2 as either a
FIG. 5. Spleen changes in 1-year-old mice. A. Representative spleens from $\mathrm{Lpla}^{+/+}$and Lpla2 ${ }^{-/-}$mice. B. Comparative weights of the wild-type and knockout spleens from 4- and 12-month-old mice are displayed. C. Phospholipid profile in the spleens obtained from Lpla $2^{+/+}$and Lpla2 $2^{-/-}$mice. The spleen homogenates obtained from

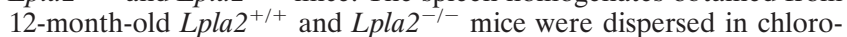
form/methanol mixture, and the lipid extraction was carried out as described in Materials and Methods. The graph denotes the phospholipid profiles of PE, PC, phosphatidylserine (PS), sphingomyelin (SM), and phosphatidylinositol (PI). The error bars indicate standard deviations $(n=4)$.

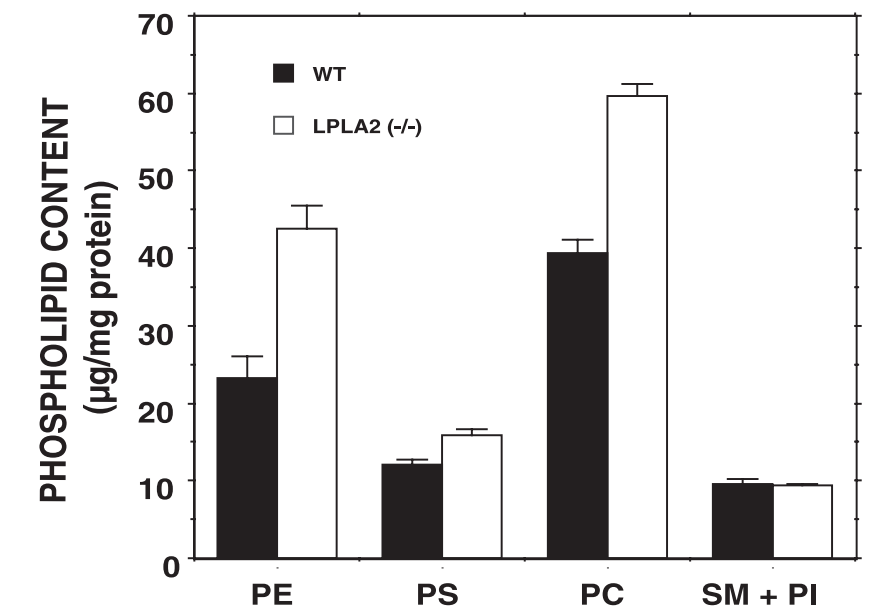

1-O-acylceramide synthase or as a phospholipase A2, the enzyme activity was abolished to greater than $95 \%$ in the lungs and alveolar macrophages of the knockout mice, suggesting that Lpla2 represents the primary acidic phospholipase A2 activity found in lung.

\section{ACKNOWLEDGMENTS}

We gratefully acknowledge the technical assistance of Lisa Riggs for the preparation of the electron micrographs. We are grateful for helpful discussions with Kent Johnson on the interpretation of the alveolar macrophage ultrastructure. We are also grateful to Thom Saunders and Elizabeth Hughes for input on the vector design and transgenic animal studies.

\section{REFERENCES}

1. Abe, A., M. Hiraoka, S. Wild, S. E. Wilcoxen, R. Paine III, and J. A. Shayman. 2004. Lysosomal phospholipase A2 is selectively expressed in alveolar macrophages. J. Biol. Chem. 279:42605-42611.

2. Abe, A., and J. A. Shayman. 1998. Purification and characterization of 1-Oacylceramide synthase, a novel phospholipase A2 with transacylase activity. J. Biol. Chem. 273:8467-8474.

3. Abe, A., J. A. Shayman, and N. S. Radin. 1996. A novel enzyme that catalyzes the esterification of $\mathrm{N}$-acetylsphingosine. Metabolism of C2-ceramides. J. Biol. Chem. 271:14383-14389.

4. Ames, G. F. 1968. Lipids of Salmonella typhimurium and Escherichia coli: structure and metabolism. J. Bacteriol. 95:833-843.

5. Bligh, E. G., and W. J. Dyer. 1959. A rapid method of total lipid extraction and purification. Can. J. Biochem. Physiol. 37:911-917.

6. Dranoff, G., A. D. Crawford, M. Sadelain, B. Ream, A. Rashid, R. T. Bronson, G. R. Dickersin, C. J. Bachurski, E. L. Mark, J. A. Whitsett, et al. 1994. 
Involvement of granulocyte-macrophage colony-stimulating factor in pulmonary homeostasis. Science 264:713-716.

7. Halliwell, W. H. 1997. Cationic amphiphilic drug-induced phospholipidosis. Toxicol. Pathol. 25:53-60.

8. Han, X., and H. Cheng. 2005. Characterization and direct quantitation of cerebroside molecular species from lipid extracts by shotgun lipidomics. J. Lipid Res. 46:163-175.

9. Han, X., and R. W. Gross. 2005. Shotgun lipidomics: electrospray ionization mass spectrometric analysis and quantitation of cellular lipidomes directly from crude extracts of biological samples. Mass Spectrom. Rev. 24:367-412.

10. Han, X., and R. W. Gross. 2005. Shotgun lipidomics: multidimensional MS analysis of cellular lipidomes. Expert Rev. Proteomics 2:253-264.

11. Han, X., J. Yang, H. Cheng, H. Ye, and R. W. Gross. 2004. Toward fingerprinting cellular lipidomes directly from biological samples by two-dimensional electrospray ionization mass spectrometry. Anal. Biochem. 330:317331.

12. Hiraoka, M., A. Abe, and J. A. Shayman. 2002. Cloning and characterization of a lysosomal phospholipase A2, 1-O-acylceramide synthase. J. Biol. Chem. 277:10090-10099.

13. Mason, R. J., J. Nellenbogen, and J. A. Clements. 1976. Isolation of disaturated phosphatidylcholine with osmium tetroxide. J. Lipid Res. 17:281-284.

14. Miles, P. R., L. Bowman, and M. J. Reasor. 1996. Exposure to crystalline silica or treatment with chlorphentermine increases vitamin E levels in rat alveolar lavage materials. J. Toxicol. Environ. Health 49:511-523.

15. Noiriel, A., P. Benveniste, A. Banas, S. Stymne, and P. Bouvier-Nave. 2004 Expression in yeast of a novel phospholipase A1 cDNA from Arabidopsis thaliana. Eur. J. Biochem. 271:3752-3764.

16. Reasor, M. J., and S. Kacew. 2001. Drug-induced phospholipidosis: are there functional consequences? Exp. Biol. Med. (Maywood) 226:825-830.

17. Six, D. A., and E. A. Dennis. 2000. The expanding superfamily of phospholipase $\mathrm{A}(2)$ enzymes: classification and characterization. Biochim. Biophys. Acta 1488:1-19.

18. Trapnell, B. C., J. A. Whitsett, and K. Nakata. 2003. Pulmonary alveolar proteinosis. N. Engl. J. Med. 349:2527-2539. 